Civic engagement of college students is readily endorsed as an aspiration in higher education; however, defining and assessing civic learning outcomes is challenging. This chapter brings clarity to the knowledge, skills, and dispositions of civic-minded graduates and offers advice on program development and assessment strategies to reach civic outcomes.

\title{
Assessing Civic Knowledge and Engagement
}

\author{
Julie A. Hatcher
}

Preparing graduates to be active citizens is a core value of colleges and universities in the United States (Knefelkamp, 2008; Sullivan, 2000). Historically, higher education has had a commitment to developing the civic commitment of its graduates; yet the degree to which this commitment is endorsed and actualized varies with time and across institutions (Stanton and Wagner, 2006; Thelin, 2004). The past two decades have seen renewed emphasis on the public purposes of higher education (Ehrlich, 2000). The Carnegie Foundation for the Advancement of Teaching now has a voluntary classification for "community engagement," and this new designation reinforces and elevates the emphasis given to this aspect of campus mission (Sandmann, Thornton, and Jaeger, 2009). However, reports by the Association of American Colleges and Universities (AACU, 2009) indicate that even though academic leaders endorse civic preparation, they also report few curricular or program strategies to reach this goal on their campuses. There is a gap between the real and ideal in terms of the degree to which programs cultivate the civic identity and participation of undergraduates (Knefelkamp, 2008).

In College Learning for the New Global Century (National Leadership Council for Liberal Education and America's Promise, 2007), consensus among colleges and universities is reflected in four broad essential learning outcomes for the twenty-first-century world. These four domains are knowledge of human cultures and the physical and natural world, intellectual and practical skills, personal and social responsibility, and integrative and applied learning. These domains for general education are also 
consistent with goals identified by future employers seeking qualified graduates to enter the twenty-first-century workplace (Hammang, 2010; Spiezio, 2009). The topic of this chapter falls within the domain of personal and social responsibility. The chapter defines civic engagement, identifies the knowledge and skills associated within civic learning outcomes, provides the theoretical foundation for development of civic identity, offers examples of successful program strategies, and describes how student learning outcomes can be assessed in general education programs.

\section{Definitional Issues}

In summer 2009, a Symposium on Assessing Students' Civic Outcomes was hosted by our Center for Service and Learning on the campus of Indiana University-Purdue University Indianapolis (IUPUI). Cosponsored by the American Association of State Colleges and Universities (AASCU) and the National Service Learning Clearinghouse, this symposium invited researchers from a variety of disciplines to share and map efforts to assess college student civic engagement so participants could build on each other's work and advance research in the field (Keen, 2009). Participants noted the problem of many definitions of student civic engagement, with each definition leading to its own assessment instrument. Such definitional issues are often symptomatic of an emerging field and areas of study such as civic engagement (Hatcher, 2010).

As participants on the Civic Engagement Rubric development team for the AACU Valid Assessment of Learning in Undergraduate Education project (Rhodes, 2010), our team of eleven faculty and staff concurred that there were differences in definitions of civic engagement in the literature; some definitions emphasized action while others emphasized democratic processes (Saltmarsh, Hartley, and Clayton, 2009). We could all agree on what a civically engaged student "looked like," but it was much more challenging to come to agreement on a common definition. Our group concluded that the following definition was most appropriate to include in the Civic Engagement Rubric (AACU, 2009) to assess student learning in the domain of civic knowledge and engagement:

Civic engagement is working to make a difference in the civic life of our communities and developing the combination of knowledge, skills, values, and motivation to make that difference. It means promoting the quality of life in a community, through both political and non-political processes [Ehrlich, 2000, p. vi].

Research under way, through the Center for Social Development at Washington University, on the International Volunteer Impacts Survey (Lough, McBride, and Sherradan, 2009) also uses this definition of civic engagement. Their research confirms that the construct is broad 
and comprises four independent, yet related, subconcepts: civic activism, community engagement, media attentiveness, and financial contributions. Additionally, the construct includes a range of behaviors, from volunteering to voting (Lough, McBride, and Sherradan, 2009).

Carol Musil (2009, p. 59) offers another definition, suggesting that "civic engagement is acting on a heightened sense of responsibility to one's communities that encompasses the notions of global citizenship and interdependence, participation in building civil society, and empowering individuals as agents of positive social change to promote social justice locally and globally."

Both of these definitions include active participation based on personal values and a sense of civic responsibility to improve society. The second definition is more expansive in its inclusion of global citizenship and social justice. Faculty must deliberate and come to a consensus on a definition of civic engagement that is most appropriate for program, campus, and institutional contexts, because the definition of civic engagement will ultimately frame and guide your assessment strategies.

\section{Conceptual Frameworks and Theoretical Foundations}

In developing the AACU Civic Engagement Rubric, our working group concluded that the "civic learning spiral" developed by the AACU (Leskes and Miller, 2006) was the strongest conceptual framework on which to build the rubric (Rhodes, 2010). The value of the civic learning spiral lies in its delineation of learning outcomes across six elements, or braids, that coexist simultaneously and are interconnected: self, communities and culture, knowledge, skills, values, and public action. These domains shape learning for both curricular and co-curricular experiences (Musil, 2009).

Colby and Damon (1992) sought to explain the "developmental process" that contributes to the origins of moral commitment. They identified six common characteristics of moral exemplars: learned optimism, sense of gratitude, personal integrity, strong social networks, faith, and moral reflection. They noted that a strong tie to others reinforced a strong sense of personal identity and personal goals; social networks bring a sense of clarity and commitment to the moral purposes of individuals. Thus interaction with others develops personal identity, and at the same time personal identity brings forth a stronger commitment to the public good. Indeed, interaction with peers has been found to be one of the essential components of sustaining and developing civic commitment during the college years (Strayhorn, 2008).

\section{Civic Knowledge}

The type of knowledge that is considered within the domain of "civic knowledge" is dependent, in part, on disciplinary perspectives. Political 
science may emphasize knowledge of political action, how a bill becomes a law, or the role of organizations to lobby and shape public policy. Philanthropic studies may emphasize knowledge of nonprofit organizations, social movements, or the role of voluntary action. Social work may emphasize the role of advocacy, collective action, or social justice. Just as the disciplines inform a variety of conceptual frameworks for the word citizen and delineation of civic skills (Battistoni, 2002), so too the disciplines inform the type of knowledge that comprises civic knowledge.

In addition to discipline-specific knowledge, there is a particular understanding about knowledge itself that constitutes the concept of civic knowledge. This frame of reference is evident in the civic learning spiral in that civic knowledge includes recognition that knowledge is dynamic, changing, and consistently reevaluated; understanding that knowledge is socially constructed and implicated with power; familiarity with key historical struggles, campaigns, and social movements to achieve the full promise of democracy; deep knowledge about the fundamental principles of and central arguments about democracy over time, as expressed in the United States and in other countries; and the ability to describe the main civic intellectual debates within one's major (Musil, 2009).

Another characteristic of civic knowledge is an understanding that "knowledge is actionable and that individuals coming together to cocreate knowledge empowers them to make positive change in the world around them" (Longo and Shaffer, 2009, p. 169). This concept of democratic knowledge validates that knowledge is co-created in partnership with communities, students, and others (Saltmarsh, Hartley, and Clayton, 2009).

\section{Civic Skills}

In terms of civic skills, a variety of skills have been identified as supporting the capacity for civic engagement. Daloz, Keen, Keen, and Parks (1996) interviewed 145 adults to understand how active citizenship is developed. Several skills associated with active citizenship were identified, among them dialogue, interpersonal perspective taking, and critical systematic thought. Further research by Keen and Hall (2008) found that "dialogue across difference" was the most critical skill in the development of civic commitments among young adults who were participants in the Bonner Scholar Program during college. Civic discourse and dialogue were also common skills identified by many of the participants in the IUPUI Symposium on Assessing Civic Outcomes (Keen, 2010).

In a working paper published by CIRCLE, a set of civic skills were identified by Mary Kirlin (2003), based on a comprehensive review of the literature in political science, education, and psychology. Kirlin presented four major categories of civic skills: organization, communication, collective decision making, and critical thinking. Examples of civic skills are 
organizing and persuading others to take action, navigating the political system, consensus building toward the common good, listening to diverse perspectives, and forming positions on public issues. These civic skills are also consistent with the participatory skills identified by the National Assessment of Educational Progress: Civics Consensus Project (U.S. Department of Education, 1998).

\section{Civic Identity}

Literature and research to date confirm the importance of identity as either a contributing factor or a fundamental aspect of civic engagement (Colby and Damon, 1992; Daloz, Keen, Keen, and Parks, 1996). The term civic identity describes the aspect of identity that leads one to take public action (Colby and Sullivan, 2009; Knefelkamp, 2008; Youniss, McLellan, and Yates, 1997). Civic identity is when people see themselves as active participants in society with a strong commitment to work with others toward the public good.

This sense of civic identity, combined with cultivation of purpose and the ability to put knowledge to responsible and practical use (Colby and Sullivan, 2009), is critical to understanding why civic engagement occurs. Consistent with college student development theory, the formation of civic identity develops over time through engagement with others.

Civic identity is related to both intellectual and ethical development, includes critical thinking and empathy for others, and is a deliberately chosen and repeated aspect of self (Knefelkamp, 2008). Research indicates that participation in organized groups during adolescence is fundamental in formation of civic identity (Youniss, McLellan, and Yates, 1997). There is a growing body of evidence that participation and peer interaction during the college years contribute to formation of lifelong civic commitments (Strayhorn, 2008).

\section{Practices That Lead to Civic Learning Outcomes}

There are numerous examples of practices used inside the classroom and through co-curricular activities to foster development of civic knowledge, skill, identity, and behavior (Colby, Ehrlich, Beaumont, and Stephens, 2003; Colby, Ehrlich, Beaumont, and Corngold, 2007; Jacoby and Associates, 2009). Student leadership programs, political action activities, and classroom teaching strategies all contribute in important ways to development of civic identity during the college years. Three practices are highlighted here.

Service Learning. The curricular strategy most clearly aligned with civic learning outcomes is service learning (Dey and others, 2009). Although there are many forms of community involvement and civic engagement, service learning represents one of the best approaches for reaching the most 
central goals of teaching students civic knowledge, skills, and habits (Battistoni, 2000; Eyler and Giles, 1999; Moely and others, 2002). Service learning is defined as a "course-based, credit-bearing educational experience in which students (a) participate in an organized service activity that meets identified community needs and (b) reflect on the service activity in such a way as to gain further understanding of course content, a broader appreciation of the discipline, and an enhanced sense of personal values and civic responsibility" (Bringle and Hatcher, 1995, p. 112). In contrast to many other examples of applied learning and community-based instruction such as cooperative education, field studies, or internships, service learning has as an intentional educational goal: the civic education and growth of students. Designing structured reflection activities (Hatcher, Bringle, and Muthiah, 2004) to reach these civic goals is fundamental to the success of this pedagogy; service in and of itself may or may not lead to civic outcomes (Ash, Clayton, and Atkinson, 2005).

The Classroom as Democratic Environment. Another course-based strategy is to transform the classroom into a democratic environment that supports and cultivates civic learning outcomes. This strategy views the classroom as more than simply a learning environment; it "also functions as a social and a political system" (Spiezio, 2009, p. 90) that invites and challenges students to develop and practice civic skills. Students take personal responsibility for their own learning, influence governance of the class, participate in peer assessment, and function as co-educators with faculty. An empirical study of Participating in Democracy Project, a model that was field-tested at eight college and universities through funding by the Teagle Foundation and Atlantic Philanthropic, demonstrated "measurable and significant differences between students enrolled in Democratic Academy classrooms and the general student population in terms of student learning outcomes relevant to the promotion of social capital" (Speizio, 2009, p. 86). Teaching resources developed from the project are readily available (Meade and Weaver, 2004).

Service-Based Scholarship Programs. The third practice to highlight is service-based scholarship programs. The Bonner Foundation's Bonner Scholars Program is a co-curricular program that supports fouryear community service scholarships for students attending twenty-seven colleges and universities. A number of program evaluations demonstrate that there are multiple benefits for students, faculty, and community partners (Keen and Hall, 2008). Influenced by a pivotal finding in earlier research (Daloz, Keen, Keen, and Parks, 1996), civic discourse is repeatedly woven into this program to foster civic engagement in adulthood. The Bonner Scholar Program is a cohort-based model that includes ongoing opportunities for interaction with others and dialogue across difference, and this is the component of the program that students report to be most valuable (Keen and Hall, 2008). On our own campus, we have designed the Sam H. Jones Community Service Scholarship Program to 
support the involvement of students in educationally meaningful service experiences (Hatcher, Bringle, Brown, and Fleischhacker, 2006). Through seven types of service-based scholarships, more than 175 students annually participate in community service, lead peers in service activities, assist faculty with implementing service learning classes, and participate in structured reflection activities. Service scholars gain leadership skills and have opportunities to be change agents on campus and in the community. Program evaluation indicates that service scholars report greater gains in civic outcomes than their peers who are not involved in cohort-based service programs.

\section{Assessment Measures}

There are many examples of ways to assess civic learning outcomes, whether through course-level or campus-level assessment strategies (Keen, 2009; see also the Bonner Foundation Network Wiki, the IUPUI Center for Service and Learning website, and the National Service Learning Clearinghouse Research Hub websites for sample measures). In addition, there are some excellent examples of longitudinal research under way at the institutional level to assess the long-term impact of civic engagement activities. Researchers at Tufts University and the University of Notre Dame have strong longitudinal research designs and findings that will shed light on which activities during the college years are of particular importance in terms of developing a civic identity.

However, assessment strategies for civic engagement are yet to fully be integrated into most campus cultures. Bringle and Hatcher (2009) examined dossiers from the first cohort of campuses that successfully applied for the Carnegie Classification for Community Engagement and concluded that the evidence presented to evaluate the extent to which service learning courses and other community-based courses met intended learning outcomes mirrors general assessment practice in higher education. Of particular concern was the finding that assessment in this first cohort was heavily dependent on self-report instruments. Some aggregation of data across the curriculum was reported, but it was quite limited and with little coordination to other forms of institutional research and institutional evaluation. The College Student Report, developed as part of the National Survey of Student Engagement (NSSE), was one example cited that permits comparison with peer institutions. Another example was the College Senior Survey (CSS) developed by the Higher Education Research Institute at the University of California, Los Angeles. Both questionnaires are limited in that they capture only student self-reports of the level of involvement in a limited range of civic activities.

The AACU Civic Engagement Rubric holds promise for assessing authentic student learning products such as e-portfolios. The rubric was designed by a team representing various disciplinary perspectives, went 
through three rounds of drafting, was field tested by a number of faculty, and was modified on the basis of feedback (Rhodes, 2010). The rubric contains six categories: diversity of communities and cultures, analysis of knowledge, civic identity and commitment, civic communication, civic action and reflection, and civic contexts and structures. Four levels are described to capture growth, from the benchmark level to the capstone level, for each category. This rubric is a tool that can be adapted and modified to align more closely with campus climate, curricular learning goals, or course-based outcomes. Along with twelve other rubrics to assess general education outcomes, it is available on the AACU website (www.aacu. org/value/rubrics/).

The AASCU has also focused on assessment of civic learning outcomes through both the American Democracy Project (Mehaffey, 2009) and the Degrees of Preparation survey funded by the Fund for the Improvement of Postsecondary Education (Hammang, 2010). The survey is designed to measure gains from the entering year to graduation, with questions "capable of measuring students' increasing preparation for participation in civic engagement, preparation for success in the workplace, and the acquisition of global skills" (Hammang, 2010, p. 8). The survey also includes an open-ended narrative prompt for students to share their personal experiences related to work and community engagement. Researchers found that students were quite willing to write about their personal experiences, and the narratives provide valuable stories that institutional leadership can use to illustrate and underscore the value of student preparation during the college years. This survey is still in the development phase and holds strong promise as a tool for institutional assessment of civic preparation during the college years.

Over the past five years, our Center for Service and Learning at IUPUI has identified the concept "civic-minded graduate" (CMG) as the "north star" for program development, assessment, and research. This work is based on an extensive literature review and consensus among program staff to identify a common set of learning outcomes for our students. We have defined a civic-minded graduate as one who is formally educated and has the capacity and orientation to work with others democratically to improve the community. Civic-mindedness is a person's inclination or disposition to be knowledgeable of and involved in the community, and to commit to act on a sense of responsibility as a member of that community (Bringle and Steinberg, 2010). As shown in Figure 7.1, the concept of CMG represents the intersection of three student attributes: self-identity, academic knowledge and skills, and civic attitudes and participation.

The thirty-item CMG scale addresses ten domains, among them knowledge of volunteer opportunities and contemporary social issues, skills in listening, diversity, consensus building, and the disposition to value community engagement in their lives and through their future career (Bringle and Steinberg, 2010). We have conducted two studies 


\section{Figure 7.1.}

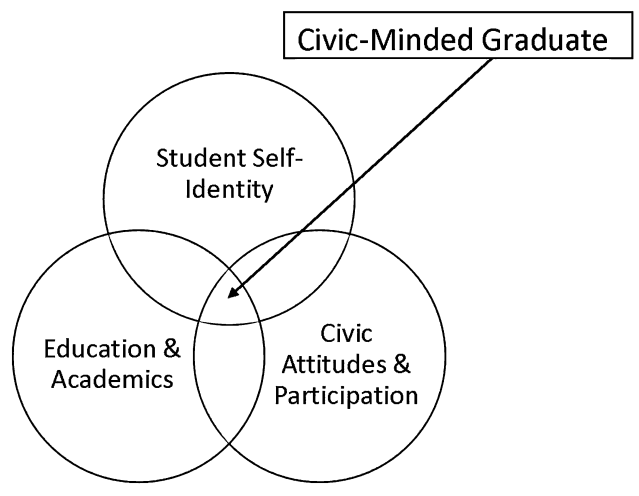

using the CMG scale, and the measure has good reliability. More important, the CMG Narrative Prompt and the accompanying CMG Rubric have been designed as tools to gather and assess authentic student work, evaluate civic learning outcomes, and validate the CMG scale. Authentic student work may be a student narrative, a student project, or a student e-portfolio. Both of these assessment tools can be found at http://csl.iupui. edu/assessment/classroomtools.cfm.

Consistent with other strategies for assessing civic outcomes (Hammang, 2010), we found that students were quite willing to write answers in response to the CMG Narrative Prompt, either as a coursebased assignment or as an open-ended question at the end of the online survey format. The CMG Narrative Prompt is phrased as shown here, with key words italicized to focus attention to each component of the prompt:

I have a responsibility and a commitment to use the knowledge and skills I have gained as a college student to collaborate with others, who may be different from me, to help address issues in society.

Please indicate the extent to which you agree or disagree with this statement by circling the appropriate number.

Strongly Strongly

Disagree

$\begin{array}{llllll}1 & 2 & 3 & 4 & 5 & 6\end{array}$

Agree

Considering your education and experiences as a college student, explain the ways in which you agree or disagree with this statement and provide personal examples when relevant.

Short and long answers on the CMG Narrative Prompt can be evaluated using the CMG Rubric, and both types have been found to positively correlate with results on the CMG survey. Departments have adapted the CMG Survey, Narrative, and Rubric to assess discipline-specific outcomes. 


\section{Conclusion}

Civic engagement is a complex term, and there are a variety of ways to involve college students in meaningful action that improves communities. Forms of civic engagement depend, in part, on campus mission and climate, administrative support, faculty disciplinary perspectives, student leadership, political climate, and community context. Much like the civic learning spiral (Musil, 2009), weaving together all of these braids creates a civic engagement spiral for each campus to enact and assess its civic engagement goals.

Institutional assessment plays an important role in improving practice in higher education. Gathering systematic data permits insight into campus culture, faculty work, and student learning. As more campuses devote resources to support development of service learning classes and civic engagement programs, it is important that assessment strategies produce information on trends, program outcomes, and effective curricular strategies. Higher education has the capacity to influence change in student learning, and also in communities and society through the active engagement of students, faculty, and graduates.

Through systematic assessment, we can gain understanding and take new and refined action to support change. John Dewey (1927) described this knowledge as social intelligence; such knowledge can lead to change, can improve society, and is vital to preserving and advancing democracy. As educators and reflective practitioners in higher education, we will do well to advance the assessment of civic learning outcomes.

\section{References}

American Association of Colleges and Universities (AACU). "VALUE Rubrics, VALUE: Valid Assessment of Learning in Undergraduate Education." 2009. Retrieved July 14, 2010, from http://www.aacu.org/value/metarubrics.cfm.

Ash, S., Clayton, P., and Atkinson, M. "Integrating Reflection and Assessment to Capture and Improve Student Learning." Michigan Journal of Community ServiceLearning, 2005, 11(2), 49-60.

Battistoni, R. "Service Learning and Civic Education." In S. Mann and J. Patrick (eds.), Education for Civic Engagement in Democracy: Service Learning and Other Promising Practices. Educational Research Information Center, Indiana University, 2000.

Battistoni, R. Civic Engagement Across the Curriculum: A Resource Book for ServiceLearning Faculty in All Disciplines. Providence, R.I.: Campus Compact, 2002.

Bringle, R., and Hatcher, J. "A Service-Learning Curriculum for Faculty." Michigan Journal of Community Service Learning, 1995, 2, 112-122.

Bringle, R., and Hatcher, J. "Innovative Practices in Service Learning and Curricular Engagement." In Institutionalizing Community Engagement in Higher Education: The First Wave of Carnegie Classified Institutions. (Special Issue.) New Directions for Higher Education, no. 147, 2009, 37-46.

Bringle, R., and Steinberg, K. "Educating for Informed Community Involvement." American Journal of Community Psychology, 2010, 46, 428-441..

Colby, A., and Damon, W. Some Do Care: Contemporary Lives of Moral Commitment. New York: Free Press, 1992. 
Colby, A., Ehrlich, T., Beaumont, E., and Corngold, J. Educating for Democracy: Preparing Undergraduates for Responsible Political Engagement. San Francisco: Jossey-Bass, 2007.

Colby, A., Ehrlich, T., Beaumont, E., and Stephens, J. Educating Citizens: Preparing America's Undergraduates for Lives of Moral and Civic Responsibility. San Francisco: Jossey-Bass, 2003.

Colby, A., and Sullivan, W. "Strengthening the Foundations of Student's Excellence, Integrity, and Social Contribution." Liberal Education, 2009, 95(1), 22-29.

Daloz, L., Keen, C., Keen, J., and Parks, S. Common Fire: Lives of Commitment in a Complex World. Boston: Beacon Press, 1996.

Dewey, J. The Public and Its Problems. Athens: Ohio University Press, 1927.

Dey, E., Barnhardt, C., Antonaros, M., Ott, M., and Holsapple, M. Civic Responsibility: What Is the Campus Climate for Learning? Washington, D.C.: Association of American Colleges and Universities, 2009.

Ehrlich, T. Civic Responsibility and Higher Education. Phoenix, Ariz.: Oryx, 2000.

Eyler, J., and Giles, D. Where's the Learning in Service-Learning? San Francisco: JosseyBass, 1999.

Hammang, J. "Beginning to Measure Learning Outcomes Affecting the Public Good." In Association of American Colleges and Universities (ed.), Rising to the Challenge: Meaningful Assessment of Student Learning Outcomes. Washington, DC: American Association of State Colleges and Universities, Association for Public and LandGrant Universities, 2010.

Hatcher, J. "Defining the Catchphrase: Understanding the Civic Engagement of College Students." Michigan Journal of Community Service Learning, 2010, 16(2), 95-100.

Hatcher, J., Bringle, R., Brown, L., and Fleischhacker, D. "Supporting Student Involvement Through Service-Based Scholarships." In E. Zlotkowski, N. Longo, and J. Williams (eds.), Students as Colleagues: Expanding the Circle of Service-Learning Leadership. Providence, R.I.: Campus Compact, 2006.

Hatcher, J., Bringle, R., and Muthiah, R. "Designing Effective Reflection: What Matters to Service-Learning?" Michigan Journal of Community Service-Learning, 2004, 11(1), 38-46.

Jacoby, B., and Associates. Civic Engagement in Higher Education: Concepts and Practices. San Francisco: Jossey-Bass, 2009.

Keen, C. "New Efforts to Assess Civic Outcomes." Journal of College and Character, 2009, 10(7), 1-6.

Keen, C. "Measuring Dialogue Across Difference as a Civic Skill." Journal of College and Character, 2010, 11(1), 1-8.

Keen, C., and Hall, K. "Post-Graduation Service and Civic Outcomes for High Financial Need Students of a Multi-Campus, Co-Curricular Service-Learning College Program." Journal of College and Character, 2008, 10(2), 1-15.

Kirlin, M. The Role of Civic Skills in Fostering Civic Engagement. CIRCLE Working Paper 6. Center for Information and Research on Civic Learning and Engagement, University of Maryland, 2003.

Knefelkamp, L. "Civic Identity: Locating Self in Community." Diversity and Democracy: Civic Learning for Shared Futures, 2008, 11(2), 1-3.

Leskes, A., and Miller, R. Purposeful Pathways: Helping Student Achieve Key Learning Outcomes. Washington, D.C.: Association of American Colleges and Universities, 2006.

Longo, N., and Shaffer, P. "Leadership Education and the Revitalization of Public Life." In B. Jacoby (ed.), Civic Engagement in Higher Education: Concepts and Practices. San Francisco: Jossey-Bass, 2009.

Lough, B., McBride, A., and Sherradan, M. "Measuring Volunteer Outcomes: Development of the International Volunteer Impacts Survey." 2009. Retrieved July 14, 2010, from http://csd.wustl.edu/ Publications/Documents/WP09-31.pdf. 
Meade, E., and Weaver, S. Toolkit for Teaching in a Democratic Academy. Allentown, Pa.: Cedar Crest College, 2004.

Mehaffy, G. Report on the Symposium on Assessing Students' Civic Outcomes. Unpublished. American Association of State Colleges and Universities, 2009.

Moely, B., Mercer, S., Ilustre, V., Miron, D., and McFarland, M. "Psychometric Properties and Correlates of the Civic Attitudes and Skills Questionnaire (CASQ): A Measure of Students' Attitudes Related to Service-Learning." Michigan Journal of Community Service-Learning, 2002, 8(2), 15-26.

Musil, C. "Educating Students for Personal and Social Responsibility: The Civic Learning Spiral." In B. Jacoby (ed.), Civic Engagement in Higher Education: Concepts and Practices. San Francisco: Jossey-Bass, 2009.

National Leadership Council for Liberal Education and America's Promise. College Learning for the New Global Century. Washington, D.C.: Association of American Colleges and Universities, 2007.

Rhodes, T. (ed.). Assessing Outcomes and Improving Achievement: Tips and Tools for Using Rubrics. Washington, D.C.: Association of American Colleges and Universities, 2010.

Saltmarsh, J., Hartley, M., and Clayton, P. Democratic Engagement White Paper. Boston: New England Resource Center for Higher Education, 2009.

Sandmann, L., Thornton, C., and Jaeger, A. (eds.). Institutionalizing Community Engagement in Higher Education: The First Wave of Carnegie Classified Institutions. (Special Issue.) New Directions for Higher Education, no. 147. San Francisco: Jossey-Bass, 2009.

Spiezio, K. "Engaging General Education." In B. Jacoby and Associates (eds.), Civic Engagement in Higher Education: Concepts and Practices. San Francisco: Jossey Bass, 2009.

Stanton, T., and Wagner, J. Education for Democratic Citizenship: Renewing the Civic Mission of Graduate and Professional Education at Research Universities. Position paper prepared for Stanford Symposium on Civic Engagement and Graduate Education at Research Universities, Stanford University, Palo Alto, Calif., Apr. 24, 2006.

Strayhorn, T. "How College Students' Engagement Affects Personal and Social Learning Outcomes." Journal of College and Character, 2008, 10(2), 1-16.

Sullivan, W. "Institutional Identity and Social Responsibility in Higher Education." In T. Ehrlich (ed.), Civic Responsibility and Higher Education. Phoenix, Ariz.: Oryx Press, 2000.

Thelin, J. A History of American Higher Education. Baltimore: John Hopkins University Press, 2004.

U.S. Department of Education. "Civic Education Survey." 1998. Retrieved July 14, 2010, from http://nces.ed.gov/surveys/cived/.

Youniss, J., McLellan, J., and Yates, M. "What We Know About Engendering Civic Identity." American Behavioral Scientist, 1997, 40(5), 620-631.

JULIE A. HATCHER is associate professor of philanthropic studies, through the Center on Philanthropy in the School of Liberal Arts, and a senior scholar with the Center for Service and Learning at Indiana University-Purdue University Indianapolis. 